\title{
Vitamin D prophylaxis in infancy
}

Sophie Jullien(1)

\begin{abstract}
We looked at existing recommendations and supporting evidence on the effectiveness of vitamin D supplementation in infancy for reducing vitamin D deficiency and for preventing rickets and infections. We also looked at optimal dose of vitamin D and the age until which vitamin D supplementation is beneficial.

We conducted a literature search up to the 17th of July 2019 by using key terms and manual search in selected sources. We summarized the recommendations and the strength of the recommendation when and as reported by the authors. We summarized the main findings of systematic reviews with the certainty of the evidence as reported. A daily dose of 400 international units of vitamin $D$ in infants has shown to be effective for improving bone health and preventing rickets. Evidence is more robust in groups of infants and children at risk. Vitamin D supplementation is well tolerated, and not associated with toxicity. Higher doses have not shown to add benefit while it could potentially cause toxic blood levels and hypercalcemia. Adequate levels of vitamin D might not be achieved with lower daily doses. Universal vitamin D supplementation starting shortly after birth, regardless of the mode of feeding and until 12 months of age, is strongly recommended. Beyond 12 months of age vitamin D supplementation is recommended only in groups of children at risk.
\end{abstract}

Keywords: 25-hydroxyvitamin D, Infants, Vitamin D supplementation, Rickets

\section{Background} Introduction

The World Health Organization (WHO) European Region is developing a new pocket book for primary health care for children and adolescents in Europe. This article is part of a series of reviews, which aim to summarize the existing recommendations and the most recent evidence on preventive interventions applied to children under 5 years of age to inform the WHO editorial group to make recommendations for health promotion in primary health care. In this article, we looked at existing recommendations and supporting evidence on the effectiveness of vitamin $\mathrm{D}$ supplementation in reducing vitamin $\mathrm{D}$ deficiency and in preventing rickets and infections.

Correspondence: sophjullien@gmail.com

The complete list of abbreviations can be accessed as supplementary file in https://doi.org/10.1186/s12887-021-02638-8.

Barcelona Institute for Global Health, University of Barcelona, Barcelona, Spain

\section{Why is vitamin $D$ important?}

Vitamin D is essential in the metabolism of calcium and phosphate, skeletal growth and bone health, but is also involved in other functions such as the modulation of the function of activated $\mathrm{B}$ and $\mathrm{T}$ lymphocytes, insulin production, the secretion of thyroid stimulating hormone and myocardial contractility [1].

\section{Context}

Vitamin D from the diet is limited, the main natural source of vitamin $\mathrm{D}$ being from the action of the sunlight on the skin. However, several factors such as cultural practices and sun protection for prevention of cancer has conditioned vitamin D deficiency and rickets to reappear as a global health problem. Low concentration of vitamin $\mathrm{D}$ in breast milk, and the recommendation of keeping newborns and infants out of direct sun exposure are all factors that contribute to the risk of vitamin D deficiency in infants [2]. Vitamin D deficiency is usually defined as serum levels of 25-hydroxyvitamin

(c) The Author(s). 2021 Open Access This article is licensed under a Creative Commons Attribution 4.0 International License, which permits use, sharing, adaptation, distribution and reproduction in any medium or format, as long as you give appropriate credit to the original author(s) and the source, provide a link to the Creative Commons licence, and indicate if changes were made. The images or other third party material in this article are included in the article's Creative Commons licence, unless indicated otherwise in a credit line to the material. If material is not included in the article's Creative Commons licence and your intended use is not permitted by statutory regulation or exceeds the permitted use, you will need to obtain permission directly from the copyright holder. To view a copy of this licence, visit http://creativecommons.org/licenses/by/4.0/ The Creative Commons Public Domain Dedication waiver (http://creativecommons.org/publicdomain/zero/1.0/) applies to the data made available in this article, unless otherwise stated in a credit line to the data. 
D lower than $50 \mathrm{nmol} / \mathrm{l}$ (equivalent to $20 \mathrm{ng} / \mathrm{ml}$ ), while serum levels superior to $75 \mathrm{nmol} / \mathrm{l}$ (equivalent to $30 \mathrm{ng} / \mathrm{ml}$ ) ensure adequate metabolic demands and health [3].

\section{Key questions}

1. Is vitamin $D$ supplementation in infancy effective in reducing vitamin $\mathrm{D}$ deficiency and in preventing rickets and infections? (Table 1)

2. Which dose of vitamin $\mathrm{D}$ is more effective and safer in preventing rickets in infancy?

3. Until which age is prophylactic vitamin D beneficial to infants?

\section{Search methods and selected manuscripts}

We described the search methods, data collection and data synthesis in the second paper of this supplement [4].

The search was conducted on the 17th of July 2019, using the search term "vitamin D". Vitamin D supplementation in infants is addressed by $\mathrm{WHO}$ and provided by the e-Library of Evidence for Nutrition Actions (eLENA). The search on the US Preventive Services Task Force (USPSTF) returned five entries, but none of them included the paediatric population, and vitamin D in children was not identified as a recommendation in progress. From the PrevInfad workgroup (Spanish Association of Primary Care Pediatrics), recommendations were found for Vitamin D prophylaxis during infancy and early childhood, although dated from August 2009. Two guidelines were identified from the National Institute for Health and Care Excellence (NICE).

The search in the Cochrane library using the date of publication from 2010 as filter yielded 63 reviews and 12 protocols. By screening the titles and abstracts, we included two systematic reviews. Twelve additional reviews were published before 2010 and we identified one relevant systematic review from 2007. We identified three protocols from which the findings of the corresponding systematics reviews would be relevant for this article. We contacted the authors of three protocols; all of them replied that their systematic review was expected to be published in the coming months. We updated the search on the 10th of October 2019, none of them were published in the Cochrane library, but we had access to the unpublished findings of the review by Huey et al.

We identified two additional studies by hand search of the references of included papers. One paper on global consensus recommendations on prevention and management of nutritional rickets, and one systematic review gathering the evidence on vitamin $\mathrm{D}$ requirements in infancy from trials published between 2009 and 2016.

All the included manuscripts for revision in this article are displayed in Table 2.

\section{Existing recommendations}

We summarized the existing recommendations and the strength of recommendations as per their authors in Table 3.

The Global consensus recommendations were established by the initiation of the European Society for Pediatric Endocrinology, based on evidence up to 2014 [17]. The expert panel included members from the Pediatric Endocrine Society, the Asia Pacific Pediatric Endocrine Society, the Japanese Society for Pediatric Endocrinology, the Sociedad Latino-Americana de Endocrinología Pediátrica, the Australasian Pediatric Endocrine Group, the Indian Society for Pediatric and Adolescent Endocrinology, the African Society for Pediatric and Adolescent Endocrinology, the Chinese Society of Pediatric Endocrinology and Metabolism, the British Nutrition Society, and the European Society for Pediatric Gastroenterology Hepatology and Nutrition.

\section{Risk factors for vitamin D deficiency}

Most recommendations refer to groups of infants and children at high risk for vitamin D deficiency. Identified risk factors for vitamin D deficiency are $[6,17,19]$ :

- In newborns and small infants:

- Maternal vitamin D deficiency: mothers with restricted sun exposure, with dark skin colour, who wear veil, multiparous, with low vitamin D intake

Table 1 Key questions for vitamin D prophylaxis in infancy

\begin{tabular}{|c|c|c|c|}
\hline & Key question 1 & Key question 2 & Key question 3 \\
\hline Participants & Infants & Infants & $\begin{array}{l}\text { Infants without risk factors } \\
\text { Infants with risk factors }\end{array}$ \\
\hline Intervention & Vitamin D supplement at any dose & Dose $A$ of vitamin $D$ & Vitamin D supplement until 12 months of age \\
\hline Comparison & Placebo or no vitamin D supplement & Dose $B$ of vitamin $D$ & Vitamin D supplement until more than 12 months of age \\
\hline Outcomes & \multicolumn{3}{|c|}{$\begin{array}{c}\text { Clinical outcomes: rickets (clinical or radiological signs), infections } \\
\text { Anthropometric outcomes such as mineral bone density } \\
\text { Levels of serum vitamin } D(25 \mathrm{OHD})\end{array}$} \\
\hline Adverse effects & \multicolumn{3}{|c|}{ Any adverse effect } \\
\hline
\end{tabular}


Table 2 Included manuscripts for revision

\begin{tabular}{|c|c|}
\hline Sources & Final selected manuscripts \\
\hline WHO & • eLENA statement (recommendations) [5] \\
\hline USPSTF & None \\
\hline Previnfad & • 2009 recommendations and supporting document [6] \\
\hline CDC & • Recommendations [7] \\
\hline \multirow[t]{2}{*}{ NICE } & • Vitamin D: supplement use in specific population groups; 2014; updated in 2017 (Guideline) [8] \\
\hline & $\begin{array}{l}\text { - Maternal and child nutrition; 2008, updated in } 2014 \text { (Guideline) [9] (Note: recommendations on vitamin D in this guideline have been } \\
\text { replaced by the Vitamin D } 2014 \text { guideline) }\end{array}$ \\
\hline \multirow{6}{*}{$\begin{array}{l}\text { Cochrane } \\
\text { Library }\end{array}$} & - Yakoob 2016 - Vitamin D supplementation for preventing infections in children under five years of age (Systematic review) [10] \\
\hline & • Winzenberg 2010 - Vitamin D supplementation for improving bone mineral density in children (Systematic review) [11] \\
\hline & • Lerch 2007 - Interventions for the prevention of nutritional rickets in term born children [12] \\
\hline & $\begin{array}{l}\text { - Yu } 2017 \text { - The effects of oral vitamin D supplementation on linear growth and non-communicable diseases among infants and children youn- } \\
\text { ger than five years of age (Protocol) [13]. Access to the unpublished stage of the systematic review: Huey } 2019 \text { [14] }\end{array}$ \\
\hline & - Tan 2018 - Vitamin D supplementation for term breastfed infants to prevent vitamin D deficiency and improve bone health (Protocol) [15] \\
\hline & - Pharande 2015 - Vitamin D supplementation for prevention of vitamin D deficiency in preterm and low birth weight infants (Protocol) [16] \\
\hline \multirow[t]{2}{*}{ Others } & $\begin{array}{l}\text { - Munns } 2016 \text { - Global consensus recommendations on prevention and management of nutritional rickets (Recommendations and } \\
\text { supporting evidence from literature review) [17] }\end{array}$ \\
\hline & - Mimouni 2017 - Vitamin D requirements in infancy: a systematic review (Systematic review) [18] \\
\hline
\end{tabular}

Abbreviations: CDC Centers for Disease Control and Prevention, NICE National Institute for Health and Care Excellence, PrevInfad Prevlnfad workgroup from the Spanish Association of Primary Care Pediatrics, USPSTF US Preventive Services Task Force, WHO World Health Organization

- Prolonged exclusive breastfeeding without vitamin D supplementation

- Preterm babies and small for gestational age

- In older infants and children:

- Decrease in vitamin D synthesis from restricted sun exposure: little time outdoors, use of protection factor $>8$ (inhibits synthesis $>95 \%)$, dark skin colour, cultural practices, veils, clothes, crystal, etc.

- Decrease in vitamin D intake: prolonged exclusive breastfeeding without supplementation, poor nutrition, low intake of foods containing vitamin D

- Certain medical conditions and chronic diseases:

- Intestinal malabsorption: small bowel disorders (such as coeliac disease), pancreatic insufficiency (such as cystic fibrosis), biliary obstruction (such as biliary atresia)

- Reduced synthesis or increased degradation of 25- $(\mathrm{OH}) \mathrm{D}$ or $1,25(\mathrm{OH})_{2} \mathrm{D}$ : chronic liver or renal diseases, treatment with rifampicin, isoniazid and anticonvulsants

\section{Existing evidence}

Three Cochrane reviews assessed the effectiveness of vitamin D supplements for improving bone health [11], on linear growth and non-communicable diseases [14], and for preventing infections [10] in children. An older Cochrane review looked at the effectiveness of vitamin D supplements for preventing rickets [12]. Although published in 2007, we included this older review in this summary as it constitutes part of the supporting evidence for current recommendations $[5,6]$.

Five studies were identified by the global consensus panel and served as reference for developing their recommendations on vitamin D supplementation for the prevention of rickets and osteomalacia [17]. Among them, one study (Beser 1994) was included in the Lerch 2007 Cochrane review, two studies [20, 21] were not included but published prior to the publication of the identified Cochrane systematic reviews for this summary, and two studies were published afterwards [22, 23]. The aim of the Mimouni 2017 systematic review was to review more recent publications (between 2009 and 2016) for new evidence related to vitamin $\mathrm{D}$ dosages in healthy infants [18].

\section{Vitamin D supplementation for preventing rickets and improving bone health}

The Lerch 2007 Cochrane review looked at the effects of several interventions (vitamin D supplementation, vitamin D and calcium supplementation, or increased sun exposure) for preventing nutritional rickets in term born children [12]. Four trials were identified and included children aged between 9 months and 2 years from China, France and Turkey. In the trial conducted in Turkey, none of the 300 children who received 400 international units (IU) per day of vitamin D developed rickets versus 14 children out of 372 from the control group (relative risk [RR] 0.04; 95\% confidence interval [CI] 0 to 0.71 ; one trial). In one trial conducted in China, authors compared a combined intervention of vitamin $\mathrm{D}$ 
Table 3 Summary of existing recommendations

\begin{tabular}{|c|c|c|c|}
\hline Sources & Ref & Date & General recommendations for use of prophylactic vitamin D in infants \\
\hline WHO & [5] & 2019 & $\begin{array}{l}\text { "Current evidence suggests that vitamin D supplements may be effective in preventing rickets, particularly for infants and } \\
\text { children who may be at higher risk due to limited sun exposure or those with darker skin pigmentation, however further } \\
\text { research is needed before specific recommendations can be made." (Category } 2 \text { intervention) }\end{array}$ \\
\hline Prevlnfad & [6] & 2009 & $\begin{array}{l}\text { Breastfed infants under one year of age have to receive vitamin D supplement of } 400 \mathrm{IU} / \text { day, starting from the first days of } \\
\text { life, and until the child is fed with one litre per day of formula milk fortified with vitamin D. (Grade B recommendation) } \\
\text { All infants under one year of age fed with substitute of human milk with less than one litre per day of formula have to } \\
\text { receive vitamin D supplement of } 400 \mathrm{IU} / \text { day. (Grade B recommendation) } \\
\text { Children or adolescents with any risk factor of vitamin D deficiency and who do not acquire } 400 \mathrm{IU} / \text { day of vitamin D with } \\
\text { one litre of fortified milk or enriched aliments (one portion of cereals and one yolk contains } 40 \mathrm{IU} \text { of vitamin D each) or } \\
\text { adequate solar exposition have to receive vitamin D supplement of } 400 \mathrm{IU} / \text { day. (Grade B recommendation) } \\
\text { For children older than one year or adolescents, daily solar exposition at midday without protection during } 10 \text { to } 15 \mathrm{~min} \text { in } \\
\text { spring, summer and fall is generally recommended for an adequate production of vitamin D. In winter, vitamin D is not } \\
\text { produced above } 42^{\circ} \text { North latitude. (Grade I recommendation) } \\
\text { Premature children under one year of corrected age need vitamin D intake of } 200 \mathrm{IU} / \mathrm{kg} / \text { day until a maximum of } 400 \mathrm{IU} / \\
\text { day. (Grade A recommendation) }\end{array}$ \\
\hline CDC & [7] & $\begin{array}{l}\text { Updated } \\
2018\end{array}$ & $\begin{array}{l}\text { "All children need vitamin D beginning shortly after birth. } \\
\text { - Children younger than } 12 \text { months old need } 400 \mathrm{IU} \text { of vitamin D each day. } \\
\text { - Children } 12 \text { to } 24 \text { months old need } 600 \mathrm{IU} \text { of vitamin D each day." } \\
\text { "Breast milk usually does not provide all the vitamin D a baby needs, so breastfed babies will need a supplemental source } \\
\text { [...]." } \\
\text { "32 oz of standard infant formula per day contains } 400 \mathrm{IU} \text { of vitamin D. If your baby is drinking less than this amount per } \\
\text { day, he or she may need a vitamin D supplement [...]." }\end{array}$ \\
\hline NICE & [9] & 2008 & $\begin{array}{l}\text { "GPs and health visitors should offer children's Healthy Start vitamin supplements (vitamins A, C and D) to all children aged } \\
\text { from } 6 \text { months to } 4 \text { years in families receiving the Healthy Start benefit." }\end{array}$ \\
\hline $\begin{array}{l}\text { Global } \\
\text { consensus }\end{array}$ & [17] & 2016 & 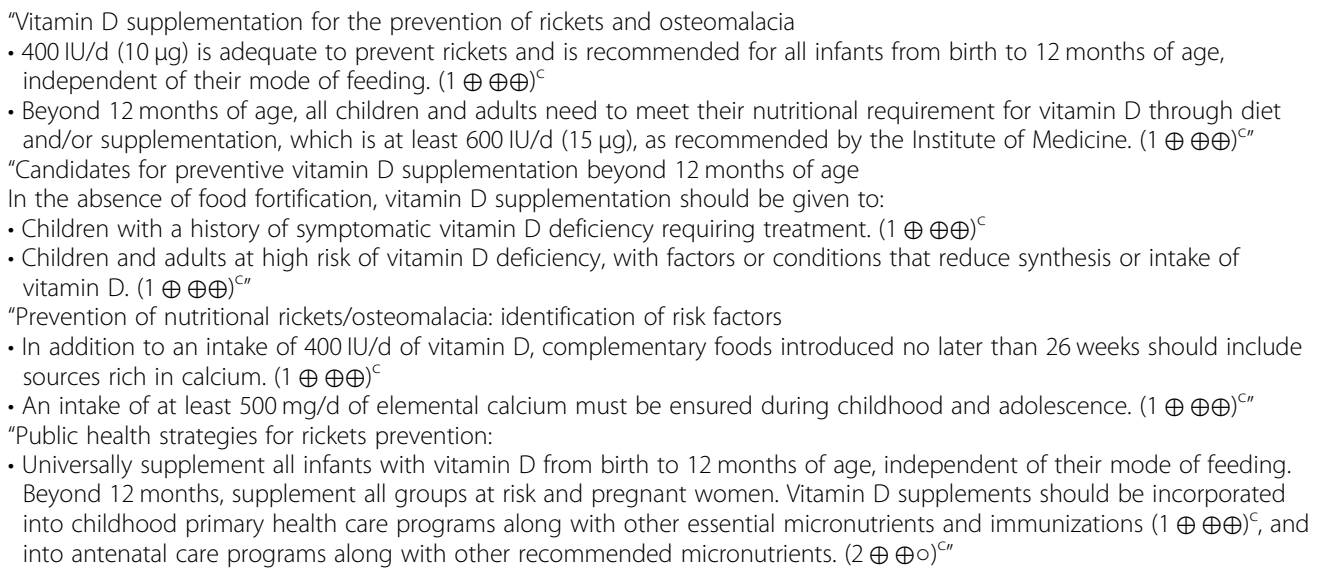 \\
\hline
\end{tabular}

Abbreviations: CDC Centers for Disease Control and Prevention, NICE National Institute for Health and Care Excellence, PrevInfad PrevInfad workgroup from the Spanish Association of Primary Care Pediatrics, USPSTF US Preventive Services Task Force, WHO World Health Organization

${ }^{a}$ The eLENA groups the interventions into three categories according to the availability of the evidence as follows. Category 1: Interventions for which there are guidelines that have been recently approved by the WHO Guidelines Review Committee. Category 1 interventions also include those supported by recommendations and other forms of guidance that have been adopted or endorsed by the World Health Assembly. Category 2: Interventions for which systematic review(s) have been conducted but no recent guidelines are yet available that have been approved by the WHO Guidelines Review Committee. Category 3: Interventions for which available evidence is limited and systematic reviews have not yet been conducted 'See paragraph below on 'Risk factors for vitamin D deficiency'

'Recommendations were graded as 1 for strong recommendation or 2 for weak recommendation; and quality of evidence was assessed as $\oplus \oplus \oplus$ high quality (prospective cohort studies or randomized controlled trials at low risk of bias), $\oplus \oplus \circ$ for moderate quality (observational studies or trials with methodological flaws, inconsistent or indirect evidence), and $\oplus \circ \circ$ for low quality (case series or non-systematic clinical observations) [17]

supplementation, calcium and nutritional counselling against no intervention. Despite low compliance in the intervention group, 100/183 children and 33/46 children developed signs of nutritional rickets in the intervention and control groups, respectively (RR 0.76 ; 95\% CI 0.61 to 0.95 ; one trial). In two trials conducted in China and France, no children developed rickets in both intervention and control groups.

In addition to the Turkish study already included in Lerch 2007, two studies were identified by the general consensus panel that looked at the effect of vitamin D supplementation for preventing rickets [17]. A randomized controlled trial (RCT) conducted in Chinese children showed that vitamin D supplementation of 100 , 200 or $400 \mathrm{IU}$ per day prevented radiographic signs of rickets at 6 months of age [21]. Similarly, two-year surveillance data from Canada showed that there was no case of radiographically confirmed rickets among infants receiving regular vitamin $\mathrm{D}$ supplementation of $400 \mathrm{IU}$ per day from birth [22]. 
As there is limited evidence from studies looking at radiological or clinical signs of rickets as outcome, we included studies that looked at other related outcomes such as levels of $25 \mathrm{OHD}$ and bone mineral density. The Winzenberg 2010 Cochrane review looked at the effectiveness of vitamin D supplementation for at least 3 months versus placebo in healthy children aged from 1 month to $<20$ years for improving bone mineral density [11]. Six RCTs (541 children receiving vitamin $\mathrm{D}$ and 343 children receiving placebo) were included for meta-analysis. These studies included children aged between eight and 17 years from Hong Kong, Finland, Pakistan and Lebanon. With a followup of one to 2 years, vitamin D had no effect on total body bone mineral density (standardized mean difference [SMD] 0.1 [95\%CI -0.06 to 0.26 ]; five studies, 672 participants; high certainty evidence) or lumbar spinal bone mineral density (SMD 0.15 [95\%CI - 0.01 to 0.31]; five studies, 660 participants; high certainty evidence), and probably had no effect on hip bone mineral density (SMD 0.06 [95\% CI -0.18 to 0.29]; four studies, 639 participants; moderate certainty evidence) and forearm bone mineral density (SMD 0.04 [95\%CI -0.36 to 0.45 ]; three studies, 427 participants; moderate certainty evidence).

\section{Vitamin D supplementation and linear growth}

The Huey 2019 Cochrane review (yet unpublished) evaluated the effects of vitamin D supplementation on linear growth [14]. For all the outcomes addressed by this review, 60 RCTs or quasi-RCTs were included. Most of them were conducted in the US, India, Finland, Canada, and Iran. The duration of follow-up for the different interventions ranged from a few days to 24 months. The main findings were as follows.

- Vitamin D supplementation in children was not associated with any significant differences in linear growth (mean length/height, in $\mathrm{cm}$ ) at the end of the supplementation period or at longterm follow-up: vitamin D versus placebo (three RCTs, 120 participants; low certainty evidence), higher-dose versus lower-dose vitamin D (eight RCTs, 240 participants; very low certainty evidence), or vitamin $\mathrm{D}$ with micronutrients versus micronutrients alone (one RCT, 25 participants; moderate certainty evidence).

- Vitamin D supplementation in children was not associated with any significant difference in height-for-age Z scores (mean HAZ scores) when compared to placebo (one RCT, 1258 participants; high certainty evidence) or to lower-dose vitamin D (two RCTs, 24 participants; very low certainty evidence).
- Vitamin D supplementation in children compared to placebo was not associated with any significant difference in the prevalence of stunting (one RCT, 1282 participants; high certainty evidence).

\section{Vitamin D supplementation and other non-communicable diseases outcomes}

The yet unpublished Cochrane review aimed to evaluate the effect of vitamin D supplementation in children on atopic diseases (this is asthma, recurring wheeze, dermatitis, and/or rhinitis) and other noncommunicable diseases (any type of cancer, type 1 and type 2 diabetes mellitus, insulin resistance, and other autoimmune disorders) as secondary outcomes [14]. They found no significant differences on atopic diseases, and they found no studies assessing other non-communicable diseases.

\section{Vitamin D supplementation for preventing infections}

The Yakoob 2016 Cochrane review looked at the effectiveness of vitamin $\mathrm{D}$ supplementation versus placebo or no intervention in children under 5 years of age for preventing infections from RCTs [10]. There was probably no benefit of vitamin D supplementation on the incidence of radiologically confirmed pneumonia (RR 1.06 [95\%CI 0.89 to 1.26]; two trials, 3134 participants; moderate certainty evidence) or diarrhoea (no effect, however meta-analysis was not possible for this outcome; two trials, 3134 participants). From one trial (3046 participants), vitamin D supplementation may not have effect on all-cause mortality (RR 1.43 (95\%CI 0.54 to 3.74 ); low certainty evidence) or on cause-specific mortality (RR 1.50 [95\%CI 0.42 to 5.30 ]; low certainty evidence).

\section{Different dosages of vitamin D supplementation for preventing rickets}

Three studies identified by Munns et al. [17] compared the effect of different dosages of vitamin $\mathrm{D}$ supplementation [20, 21, 23]. In their consensus statement, the expert panel added that "Among infants and toddlers with $25 \mathrm{OHD}$ levels $<50 \mathrm{nmol} / \mathrm{L}$ for whom daily vitamin $\mathrm{D}$ supplementation may not be ideal, intermittent bolus doses of 50 to 100000 IU every 3 months hold promise, although a comprehensive understanding of the safety and efficacy of this approach remains to be studied" [17]. The Mimouni 2017 review [18] identified 11 manuscripts from nine RCTs looking at the effect of different doses of vitamin D supplementation in healthy infants [23-33], including one of the three studies identified by Munns et al. [23]. Authors concluded that "there is no additional evidence that larger, more generous amounts of daily vitamin D beyond the recommended $400 \mathrm{IU}$ daily dose, affects any long-term significant outcome. It even appears that larger amount may lead to serum 
Table 4 Characteristics and main findings of studies looking at different doses of vitamin D supplementation [17, 18]

\begin{tabular}{|c|c|c|c|c|}
\hline Ref & $\begin{array}{l}\text { Setting, date } \\
\text { of } \\
\text { publication }\end{array}$ & Participants & $\begin{array}{l}\text { Interventions: regimens } \\
\text { of vitamin D }\end{array}$ & Findings \\
\hline [21] & China 1992 & 312 healthy term infants & $\begin{array}{l}\text { (A) } 100 \mathrm{IU} / \text { day } \\
\text { (B) } 200 \mathrm{IU} / \text { day } \\
\text { (C) } 400 \mathrm{IU} / \text { day } \\
\text { Initiated at } 3 \text { to } 5 \text { days of } \\
\text { life, up to } 6 \text { months of } \\
\text { age. }\end{array}$ & $\begin{array}{l}\text { Adequate levels of } 25 \mathrm{OHD} \text { above the rachitic range (equivalent to severe } \\
\text { deficiency of less than } 11 \mathrm{ng} / \mathrm{mL} \text { ) were more frequently achieved among } \\
\text { infants receiving the } 400 \mathrm{IU} \text { dosages compared to the } 100 \text { and } 200 \mathrm{IU} \\
\text { dosages. }\end{array}$ \\
\hline [20] & $\begin{array}{l}\text { Afghanistan } \\
1994\end{array}$ & $\begin{array}{l}\text { Infants with vitamin D } \\
\text { deficiency }(25 \mathrm{OHD}<25 \\
\mathrm{nmol} / \mathrm{L})\end{array}$ & $\begin{array}{l}\text { (A) Single dose of } 600,000 \\
\text { IU at birth } \\
\text { (B) Single dose of } 200,000 \\
\text { IU at birth } \\
\text { (C) } 100,000 \text { IU at birth, } 3 \\
\text { and } 6 \text { months }\end{array}$ & $\begin{array}{l}\text { (C) provided the best protection against vitamin } \mathrm{D} \text { deficiency without } \\
\text { reaching unacceptably high concentrations of } 25 \mathrm{OHD} \text {. }\end{array}$ \\
\hline
\end{tabular}

[24] Louisiana 201080 breastfed babies

[26] Iran $2010 \quad-129$ infants

[27] Spain $2011 \quad 88$ term infants, not all exclusively breastfed

[28] Germany 201140 term infants

[29] Finland 2012

113 breastfed infants recruited at 2 weeks of age

[30] Turkey 2013169 breastfed term babies

$\begin{array}{ll}\text { [31] Canada } 2013 & 51 \text { term infants } \\ \text { [23] Canada 2013 } & \begin{array}{l}132 \text { breastfed infants } \\ \text { recruited at 1 month of } \\ \text { age }\end{array}\end{array}$

[32] Canada 2016
(A) $200 \mathrm{IU}$ from day 1 to 6 months

(B) $200 \mathrm{IU}$ from month 2

to 6 months

(C) placebo

(A) $200 \mathrm{IU} /$ day

(B) $400 \mathrm{IU} /$ day

(C) $50,000 \mathrm{IU} /$ month

(A) 400 IU/day for 12

months

(B) No vitamin D

supplements

(A) 250 IU/day

(B) $500 \mathrm{IU} /$ day Starting in summer or in winter, follow-up of 6 weeks.

(A) $400 \mathrm{IU} /$ day

(B) $1200 \mathrm{lU} / \mathrm{day}$

(C) $1600 \mathrm{IU} /$ day

Follow-up of 12 weeks.

(A) $200 \mathrm{IU} /$ day

(B) $400 \mathrm{IU} /$ day

(A) Vit $D_{2} 400$ IU/day

(B) Vit $D_{3} 400 \mathrm{IU} /$ day

(A) $400 \mathrm{IU} /$ day

(B) $800 \mathrm{IU} / \mathrm{day}$

(C) $1200 \mathrm{IU} /$ day

(D) $1600 \mathrm{IU} /$ day

Follow-up for 11 months, reassessed at 1 year of age.

Follow-up of [23] at 3 years Same as above of age
No differences in 25OHD, Calcium, or Phosphorous concentrations between (A) and (B) at 2, 4, and 6 months of age.

At 4 months of age, the 25OHD serum concentration of (C) was significantly lower than (A) and (B).

No cases of rickets in any of the 3 groups.

Author conclusion "universal supplementation is not necessary for rickets prevention in Southern Louisiana"

Serum 25OHD concentration at 6 months of age:

(A) 20 to $51 \mathrm{ng} / \mathrm{ml}$

(B) 23 to $64 \mathrm{ng} / \mathrm{ml}$

(C) 28 to $102 \mathrm{ng} / \mathrm{ml}$

Serum 250HD concentration:

- At 3 months of age: (A) $41.8+/-16.7 \mathrm{ng} / \mathrm{ml}$; (B) $27.6+/-12.8 \mathrm{ng} / \mathrm{ml} ; p<$ 0.001

- At 6 months of age: (A) $43.8+/-13.8 \mathrm{ng} / \mathrm{ml}$; (B) $32.5+/-8.9 \mathrm{ng} / \mathrm{ml} ; \mathrm{p}<$ 0.001

- At 12 months of age: no differences between (A) and (B)

Parathyroid hormone: no differences between (A) and (B) at any time. No clinical rickets in neither group.

Serum $25 \mathrm{OHD}$ concentrations at six weeks:

(A) $45.6 \mathrm{ng} / \mathrm{ml}$ to $65.6 \mathrm{ng} / \mathrm{ml}$

(B) $50 \mathrm{ng} / \mathrm{ml}$ to $70 \mathrm{ng} / \mathrm{ml}$

No seasonal variations in $25 \mathrm{OHD}$ concentrations.

Only (C) maintained serum $25 \mathrm{OHD}$ concentration $>32.5 \mathrm{ng} / \mathrm{mL}$ in all infants without hypercalcemia or hypercalciuria. In (B) and (C) some infants reached $25 \mathrm{OHD}$ concentrations $>80 \mathrm{ng} / \mathrm{mL}$.

Bone density (peripheral quantitative computed tomography): no significant differences between the 3 groups.

Serum $250 H D$ concentrations at 4 months:

(A) median of $39.6 \mathrm{ng} / \mathrm{ml}$ (range 17.05 to 106 )

(B) median of $56.5 \mathrm{ng} / \mathrm{ml}$ (range 32 to 150.2); with significant differences ( $p<$ 0.001)

Proportion of infants with serum $25 \mathrm{OHD}<30 \mathrm{mg} / \mathrm{ml}$ at 4 months:

(A) $21.3 \%$

(B) $0 \%$

No clinical rickets in either group.

No differences in increase of plasma 25OHD from baseline between (A) and (B) after 3 months

Plasma $25 \mathrm{OHD}$ levels of $\geq 50 \mathrm{nmol} / \mathrm{L}$ ( $20 \mathrm{ng} / \mathrm{ml}$ ) in $97 \%$ (95\% Cl 94 to 100 ) of infants at 3 months, and sustained in $98 \%$ (95\% Cl 94 to 100) of infants at 12 months in all groups.

Plasma $25 \mathrm{OHD}$ concentration $\geq 75 \mathrm{nmol} / \mathrm{L}(30 \mathrm{ng} / \mathrm{ml})$ in $97.5 \%$ of infants at 3 months only in (D).

The (D) dose led to $25 \mathrm{OHD}$ concentration (> $150 \mathrm{ng} / \mathrm{ml}$ ) that may cause hypercalcemia (potential toxicity).

No differences in growth and bone mineral content between groups. Authors concluded that "dosages of vitamin D higher than 400 IU per day provide no additional benefits for bone mineral accretion."

Bone health at 3 years of age:

"Lumbar spine vertebrae 1-4 bone mineral density, lumbar spine and whole body bone mineral content, and mineral accretion, measured by dual-energy 
Table 4 Characteristics and main findings of studies looking at different doses of vitamin D supplementation [17, 18] (Continued)

\begin{tabular}{|c|c|c|c|c|}
\hline Ref & $\begin{array}{l}\text { Setting, date } \\
\text { of } \\
\text { publication }\end{array}$ & Participants & $\begin{array}{l}\text { Interventions: regimens } \\
\text { of vitamin D }\end{array}$ & Findings \\
\hline & & & & X-ray absorptiometry were similar among all treatment groups." \\
\hline [33] & Canada 2017 & $\begin{array}{l}\text { Follow-up of [23] at } 3 \text { years } \\
\text { of age }\end{array}$ & Same as above & $\begin{array}{l}\text { Body composition (by anthropometric measurements and from the dual- } \\
\text { energy X-ray absorptiometry measurements): no differences between the } 3 \\
\text { groups. } \\
\text { "However when all infants were combined, there was a weak correlation } \\
\text { between } 25 \mathrm{OHD} \text { measurements and lean body mass, although this correlation } \\
\text { may have only reflected subtle differences in outdoors physical activity rather } \\
\text { than differences because of treatment group allocation." }\end{array}$ \\
\hline [25] & $\begin{array}{l}\text { Afghanistan } \\
2013\end{array}$ & $\begin{array}{l}3046 \text { children between } 1 \\
\text { and } 11 \text { months of age }\end{array}$ & $\begin{array}{l}\text { Vitamin D: } \\
\text { (A) 100,000 IU/3 months; } 6 \\
\text { doses } \\
\text { (B) Placebo/3 months; } 6 \\
\text { doses }\end{array}$ & $\begin{array}{l}\text { Occurrence of diarrheic episodes during the 18-months follow-up period: no } \\
\text { significant differences between (A) and (B). } \\
\text { Serum 25OHD concentrations: not assessed. }\end{array}$ \\
\hline
\end{tabular}

$25(\mathrm{OH}) \mathrm{D}$ concentrations that have been reported to be potentially associated with adverse effects." The basic characteristics and main findings of the 13 studies identified by these two reviews are summarized in Table 4.

\section{Duration of administration of vitamin D supplementation} While most of the sources recommend vitamin D supplementation in all infants for the first 12 months of age, there is a lack of strong evidence supporting this duration of administration of 12 months. Assessment of risk factors including the overall vitamin D intake through milk and foods containing vitamin D and sun exposure seem key factors leading to the established recommendations.

\section{Adverse effects}

Vitamin D supplementation was well tolerated according to the trials included in Winzenberg 2010 [11]. None of the included trials in Yakoob 2016 reported any adverse effect of vitamin D supplementation, although one infant was found to have high concentration of vitamin $\mathrm{D}$ in one trial with no clinical repercussion, and two children had toxic concentrations of vitamin D in another included trial [10].

The recent, yet unpublished Cochrane review evaluated adverse events of oral vitamin D and found that there were no significant differences in the risk of hypercalciuria, hypercalcemia, nor hyperphosphatemia between oral vitamin D and either placebo, lower doses of vitamin D or micronutrients [14].

\section{Summary of findings}

- All infants should receive vitamin D for improving bone health and preventing rickets, starting shortly after birth, regardless of the mode of feeding. Evidence is more robust to support this recommendation in groups of infants and children at risk.
- There is probably no benefit of universal vitamin D supplementation in infants on the incidence of radiologically confirmed pneumonia or diarrhoea.

- A daily dose of 400 international units of vitamin D in infants has shown to be effective for preventing rickets. It is well tolerated, and not associated with toxicity. Higher doses have not shown to add benefit while it could potentially cause toxic blood levels and hypercalcemia. Adequate levels of vitamin D might not be achieved with lower daily doses.

- Universal vitamin D supplementation until 12 months of age is strongly recommended. Beyond 12 months of age vitamin D supplementation is recommended only in groups of children at risk. There is however a lack of evidence supporting this cut off of 12 months, so this age cut off seems arbitrary.

\section{Acknowledgments}

I am very grateful to María Jesús Esparza, Laura Reali, and Gottfried Huss for carefully reviewing and providing valuable feedback for each article. I am also grateful to Ralf Weigel and Gottfried Huss for proofreading the final version of this document.

\section{About this supplement}

This article has been published as part of BMC Pediatrics Volume 21, Supplement 1 2021: Defined preventive interventions for children under five years of age: evidence summaries for primary health care in the WHO European region. The full contents of the supplement are available at https://bmcpediatrics.biomedcentral.com/articles/supplements/volume-21supplement-1.

\section{Author's contributions}

SJ was identified as the researcher in the development of the synthesis of evidence and writing the report. For each selected topic on preventive interventions, SJ defined the key questions, established and run the literature search, screened the returned manuscripts for eligibility, extracted data and summarized the existing recommendations and supporting evidence. The principal advisors of this project were Dr. Gottfried Huss, MPH General Secretary of ECPCP, Project- Coordinator and Prof. Ralf Weigel, Friede Springer endowed professorship of Global Child Health, Witten/Herdecke University (scientific advice). The author(s) read and approved the final manuscript. 


\section{Funding}

Publication charges for this article have been funded by the Friede Springer endowed professorship for Global Child Health at the Witten Herdecke University, Germany.

\section{Availability of data and materials}

Not applicable.

\section{Declarations}

\section{Ethics approval and consent to participate}

Not applicable.

\section{Consent for publication}

Not applicable.

\section{Competing interests}

SJ had a contract and was paid as an independent consultant by the WHO via Witten/ Herdecke University, ECPCP and EPA/UNEPSA for developing the different articles of this supplement.

\section{Published: 8 September 2021}

\section{References}

1. Wagner CL, Greer FR. Section on breastfeeding and committee on nutrition. Prevention of rickets and vitamin D deficiency in infants, children, and adolescents. Pediatrics. 2008;122(5):1142-52. https://doi.org/10.1542/peds.2 008-1862.

2. Streym SV, Højskov CS, Møller UK, Heickendorff L, Vestergaard P, Mosekilde L, et al. Vitamin D content in human breast milk: a 9-mo follow-up study. Am J Clin Nutr. 2016;103(1):107-14. https://doi.org/10.3945/ajcn.115.115105.

3. Holick MF, Chen TC. Vitamin D deficiency: a worldwide problem with health consequences. Am J Clin Nutr. 2008:87(4):1080-6.

4. Jullien S, Huss G, Weigel R. Supporting recommendations for childhood preventive interventions for primary health care: elaboration of evidence synthesis and lessons learnt. BMC Pediatrics. 2021. https://doi.org/10.1186/ s12887-021-02638-8.

5. WHO. Vitamin D supplementation in infants [Internet]. eLENA. 2019 [cited 2019 Jun 6]. Available from: https://www.who.int/elena/titles/vitamind_infa nts/en/

6. Alonso Díaz C, Ureta Velasco N, Pallás Alonso CR. Recomendaciones Previnfad/PAPPS [Internet]. 2009 [cited 2019 Jun 6]. p. 1-10. Available from: http://previnfad.aepap.org/monografia/vitamina-d

7. CDC. Vitamin D [Internet]. 2018 [cited 2019 Jul 17]. Available from: https:// www.cdc.gov/nutrition/InfantandToddlerNutrition/vitamins-minerals/vita min-d.html

8. NICE. Vitamin D: supplement use in specific population groups [Internet] 2014 [cited 2019 Jul 19]. Available from: www.nice.org.uk/guidance/ph56.

9. NICE. Maternal and child nutrition [Internet]. 2008 [cited 2019 Jul 19]. Available from: www.nice.org.uk/guidance/ph11.

10. Yakoob M, Salam R, Khan F, Bhutta Z. Vitamin D supplementation for preventing infections in children under five years of age (Review). Cochrane Database Syst Rev. 2016:11:CD008824.

11. Winzenberg T, Powell S, Shaw K, Jones G. Vitamin D supplementation for improving bone mineral density in children (Review). Cochrane Database Syst Rev. 2010;10:CD006944.

12. Lerch $\mathrm{C}$, Meissner $\mathrm{T}$. Interventions for the prevention of nutritional rickets in term born children (Review). Cochrane Database Syst Rev. 2007;4:CD006164.

13. Yu E, Huey S, Peña-Rosas J, Mehta S. The effects of oral vitamin $D$ supplementation on linear growth and non-communicable diseases among infants and children younger than five years of age (Protocol). Cochrane Database Syst Rev. 2017;11:CD012875

14. Huey S, Acharya N, Silver A, Sheni R, Yu E, Peña-Rosas J, et al. The effects of oral vitamin D supplementation on linear growth and non-communicable diseases among infants and children younger than five years of age (Review) In press. Cochrane Database Syst Rev. 2019;8:CD012875.

15. Tan M, Abrams S, Osborn D. Vitamin D supplementation for term breastfed infants to prevent vitamin D deficiency and improve bone health (Protocol). Cochrane Database Syst Rev. 2018;6:CD013046.
16. Pharande P, Pammi M, Collins C, Zhou S, Abrams S. Vitamin D supplementation for prevention of vitamin D deficiency in preterm and low birth weight infants (Protocol). Cochrane Database Syst Rev. 2015;2:CD011529.

17. Munns CF, Shaw N, Kiely M, Specker BL, Thacher TD, Ozono K, et al. Global consensus recommendations on prevention and management of nutritional rickets. J Clin Endocrinol Metab. 2016;101(2):394-415. https://doi.org/10.121 0/jc.2015-2175.

18. Mimouni FB, Huber-Yaron A, Cohen S. Vitamin D requirements in infancy : a systematic review. Curr Opin Clin Nutr Metab Care. 2017;20(3):232-6. https:// doi.org/10.1097/MCO.0000000000000368.

19. Munns C, Zacharin MR, Rodda CP, Batch JA, Morley R, Cranswick NE, et al. Prevention and treatment of infant and childhood vitamin D deficiency in Australia and New Zealand: a consensus statement. Med J Aust. 2006;185(5): 268-72. https://doi.org/10.5694/j.1326-5377.2006.tb00558.x.

20. Zeghoud F, Ben-Mekhbi H, Djeghri N, Garabédian M. Vitamin D prophylaxis during infancy: comparison of the long-term effects of three intermitent doses $(15,5$, or $2.5 \mathrm{mg})$ on 25 -hydroxyvitamin D concentrations. Am J Clin Nutr. 1994;60(3):393-6. https://doi.org/10.1093/ajcn/60.3.393.

21. Specker BL, Ho ML, Oestreich A, Yin T, Shui Q, Chen X, et al. Prospective study of vitamin D supplementation and rickets in China. J Pediatr. 1992; 120(5):733-9. https://doi.org/10.1016/S0022-3476(05)80236-7.

22. Ward LM, Gaboury I, Ladhani M, Zlotkin S. Vitamin D-deficiency rickets among children in Canada. Can Med Assoc J. 2007;177(2):161-6. https://doi. org/10.1503/cmaj.061377.

23. Gallo S, Comeau K, Vanstone C, Agellon S, Sharma A, Jones G, et al. Effect of different dosages of oral vitamin $D$ supplementation on vitamin $D$ status in healthy, breastfed infants. JAMA. 2013;309(17):1785-92. https://doi.org/10.1 001/jama.2013.3404.

24. Ponnapakkam T, Bradford E, Gensure R. A treatment trial of vitamin D supplementation in breastfed infants: universal supplementation is not necessary for rickets prevention in southern Louisiana. Clin Pediatr (Phila). 2010;49(11):1053-60. https://doi.org/10.1177/0009922810376320.

25. Aluisio A, Maroof Z, Chandramohan D, Bruce J, Mughal MZ, Bhutta Z, et al. Vitamin D3 supplementation and childhood diarrhea: a randomized controlled trial. Ped. 2013:132(4):e832-40. https://doi.org/10.1542/peds.2012-3986.

26. Shakiba M, Sadr S, Nefei Z, Lotfi MH, Bemanian MH. Combination of bolus dose vitamin $D$ with routine vaccination in infants: a randomised trial. Singap Med J. 2010;51(5):440-5

27. Alonso A, Rodríquez J, Carvajal I, Prieto ML, Rodriquez RM, Pérez AM, et al. Prophylactic vitamin D in healthy infants: assessing the need. Metabolism. 2011;60(12):1719-25. https://doi.org/10.1016/j.metabol.2011.04.011.

28. Siafarikas A, Piazena H, Feister U, Bulsara MK, Meffert H, Hesse V. Randomised controlled trial analysing supplementation with 250 versus 500 units of vitamin D3, sun exposure and surrounding factors in breastfed infants. Arch Dis Child. 2011;96(1):91-5. https://doi.org/10.1136/adc.2009.178301.

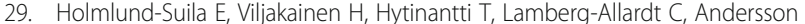
$S$, Mäkitie O. High-dose vitamin D intervention in infants - effects on vitamin D status, calcium homeostasis, and bone strength. J Clin Endocrinol Metab. 2012;97(11):4139-47. https://doi.org/10.1210/jc.2012-1575.

30. Atas E, Karademir F, Ersen A, Meral C, Aydmoz S, Suleymanoglu S, et al. Comparison between daily supplementation doses of 200 versus $400 \mathrm{IU}$ of vitamin D in infants. Eur J Pediatr. 2013;172(8):1039-42. https://doi.org/10.1 007/s00431-013-1997-4.

31. Gallo S, Phan A, Vanstone CA, Rodd C, Weiler HA. The change in plasma 25hydroxyvitamin $\mathrm{D}$ did not differ between breastfed infants that received a daily supplement of ergocalciferol or cholecalciferol for 3 months. J Nutr. 2013:143:148-53.

32. Gallo S, Hazell T, Vanstone C, Agellon S, Jones G, Abbé M, et al. Vitamin D supplementation in breastfed infants from Montréal, Canada: 25-hydroxyvitamin $D$ and bone health effects from a follow-up study at 3 years of age. Osteoporos Int. 2016:27(8):2459-66. https://doi.org/10.1007/s00198-016-3549-z.

33. Hazell T, Gallo S, Vanstone C, Agellon S, Rodd C, Weiler H. Vitamin D supplementation trial in infancy: body composition effects at 3 years of age in a prospective follow-up study from Montréal. Pediatr Obes. 2017;12(1): 38-47. https://doi.org/10.1111/ijpo.12105.

\section{Publisher's Note}

Springer Nature remains neutral with regard to jurisdictional claims in published maps and institutional affiliations. 